\title{
Gamification and Using It in Organisational Consulting
}

\author{
DMaija Zakrizevska-Belogrudova ${ }^{1}$ Dr. psych.; Sanita Leimane ${ }^{2}$ Mg.sc. administr. \\ RISEBA University of Applied Sciences, Latvia \\ maija.zakrizevska@ riseba.lv11; leimanesanita@gmail.com²
}

\begin{abstract}
Gamification has been a topical item in education, marketing, human resources management, business, and organisational consulting in the past decade. Nowadays, companies have a wider range of available organisational consultations: organisational supervision is developing, coaching is popular, and there is a wide offer of business training sessions. This study aims to research gamification in organisational consulting, analyse the differences in the opinions regarding the use and availability of gamification in the professional activities of coaches, supervisors and business trainers. The survey developed by the authors of the study consisted of four sets of items (Information about Gamification, Application and Availability of Gamification, Believing Gamification Methods, Team/Group Responsiveness to Gamification) and two additional statements for the purpose of confirming the responses given by the respondents regarding their beliefs in gamification as an effective method and their readiness to use it. The associations related to the game and gamification were also researched. The questionnaire about gamification in the professional activities of supervisors, coaches and business trainers was sent electronically to professionals practising in Latvia. Questionnaires from 85 respondents were received and processed. The results demonstrated no statistically significant differences in the opinions of coaches, supervisors and business trainers regarding the use of gamification in organisational consulting. It was found out that the concept of gamification has not been sufficiently explained and there is still no common understanding regarding it in Latvia. More than half or $55 \%$ of the 85 respondents in the survey do not know where to acquire gamification. At the same time, $91 \%$ of the respondents in the survey specify that they are willing to acquire the methods of gamification. The authors of the study believe that it is important to proceed with the research in organisations to find out the experience of the organisations in gamification and to develop gamification training programmes for the organisations.
\end{abstract}

Keywords: gamification, organisational supervision, coaching, organisational consulting.

\section{Introduction}

Gamification has been a topical item in education, marketing, business and organisational consulting in the past decade. Nowadays, more than $40 \%$ of the top 1,000 organisations in the world use gamification as the primary mechanism in the transformation of their business operations (Hayward, 2017). As anticipated by some future strategists, gamification has constantly increasing impacts on human life not only within organisations, but also outside them (How to Succeed..., 2018; Schnell, 2010). Y.K. Chou also specifies that, over the past few years, gamification has reached a social breakpoint and is starting to emerge in every aspect of life from education, work, marketing, upbringing of children, sustainability to even the healthcare sector and scientific testing (Chou, 2019). The international gamification market was 5.5 billion US Dollars in 2018, already 7.17 billion in 2019, and a substantial growth is still being anticipated to reach 12 billion US Dollars in 2021. It is largely rapid due to the technological innovations, particularly the tremendous number of mobile devices already being manufactured with a wide base of settings adapted to the needs of the gamification market (Joy, 2020). The increase is also being experienced due to the fact that gamification systems are becoming increasingly acknowledged as suitable in the formation of human behaviour for the purpose of supporting innovation, engagement and productivity (Gamification market..., 2020).

The simplest and most widely published definition of gamification reads as follows: gamification is the application of game design elements in non-game contexts. (Deterding et al., 2011). Other, more detailed definitions are also available. For example, gamification is taking the most essential from a game and applying it for real business targets (Saran, 2015). Or, for instance, gaming expert K.M. Kapp believes that gamification is the use of game-based mechanisms, game design and game thinking to engage people, motivate action, facilitate learning and solve problems (Kapp, 2012). Gamification is a simple concept for making non-game systems or processes more attractive by using the principles of a game (Bishop, 2014). Generally speaking, the aim of gamification is to change something in a game so that the behaviour is 
changed or, in other words, a game becomes more than just absolute entertainment (Hayward, 2017). Gamification offers the best tools mankind has ever invented to create and maintain engagement of people in work (Zichermann, Linder, 2013). The size of the organisation is of no significance, the biggest challenge is the engagement of the employees in work (Padgett, 2013). The significance of engagement in work is also emphasised by B. Bruke, who provides the following definition for gamification: "Gamification is the application of game mechanisms and design experience for the purpose of digitally engaging and motivating people to achieve their targets" (Bruke, 2014). Highlighting the substantial role of gamification nowadays, B. Bruke has said: "Gamification creates entirely new work engagement models by reaching new communities of people and motivating them to achieve targets they even might not have been aware of!" (Bruke, 2014). The author also specifies that gamification is a powerful, goaloriented approach in the engagement and motivation of people while, in the meantime, pursuing the aims of the organisation. Gamification can be used to motivate people to change their behaviour, develop skills, and guide innovation. A key factor of success in gamification is engaging people on emotional level, by motivating them to attain the set targets (Bruke, 2014). Engagement of employees covers everything with own engagement in work, with the management and leaders, with anyone else, and with the organisation (Zinger, 2014). Nowadays, gamification is mostly applied in training sessions and education by encouraging innovation and increasing the performance of the employees, focusing on the areas with clear targets, including sales and other support areas (Mathieson, 2017). One of the gamification trends is that it is more frequently applied in corporate learning, business training, partially or fully gamified systems which meet most of the corporate training needs are used (Pandey, 2019). Gamification is used in many more professional fields, including pedagogy (Lukashenia, Levanova, Tamarskaia, 2020).

A survey of the situation in Latvia, i.e., the gamification practices and experiences, the most frequently used games and their elements, leads to a conclusion that organisations have little information. However, a doctoral thesis on the impact of gamification on employee engagement in a complex system of human resource management processes (Ërgle, 2020) was defended very recently. The Educational Games and Methods Association has been operating in Latvia since 2018 and unites the authors of games and other interested parties. The most well-known event in the organisation of which the Association has been participating several times in collaboration with the developers of games is The Carousel of Methods during which the interested parties and anyone using gamification in organisations (including supervisors, coaches and business trainers) can learn information about the latest games and attend seminars and workshops. Company Tavas Metodes has also been operating actively in the area of games and methods. The organisation offers interactive and gnostic methods as well as games for professionals for working with personal and professional growth of people, relationships, and emotions (Par mums, 2018). Additionally, the benefits.lv internal communication platform for the engagement and evaluation of employees is operating in Latvia. The company provides employers with personnel engagement and motivation tools to use as rewards to the employees for their loyalty, allowing them to choose the benefits they are interested in, to create positive motivation and facilitate engagement and work productivity. It helps companies to become better aware of the needs and interests of their employees, whereas the employees gain access to a personalised account where they can manage the benefits awarded to them (Ceḷa pie laimīgiem..., 2020). A similar platform is efectio.lv which offers a digital micro learning platform supplemented with elements of gamification to give an opportunity to educate, engage and unite company employees with a modern human resource management approach (Efectio programmu piedāvājums..., 2020).

The aim of the study is to research gamification in organisational consulting, analyse the differences in the opinions regarding the use and availability of gamification in the professional activities of coaches, supervisors and business trainers.

Research questions: Are gamification methods used in organisational consulting in Latvia? What information about gamification is available in Latvia? Are there significant differences in the opinions of consultants of various types (coaches, supervisors, business trainers) regarding the use of gamification?

A tendency observed in Latvian companies is that they purposefully plan and introduce elements of a game not only as a bridge between the clients and the services/product of the company, but also as a tool in the personnel management processes, including learning, in the so-called onboarding processes and elsewhere (Rūsa, 2016). The summary leads to a conclusion that there are some organisations in Latvia which make games, there are Internet platforms based on gamification solutions as offers to organisations, games are 
developed or adapted by various learning and business training enterprises. However, there is no vision of the overall development of this area, and there is also no such information. Therefore, it is important to explore the opportunities available to supervisors, coaches and business trainers (henceforth referred to as consultants) for the use of gamification. The research in the practical part is also based on analysis of the experience of the professionals from these three areas in the use of gamification.

\section{Methodology}

Study procedure. The primary data have been obtained using a questionnaire developed by the authors of the research study. The questionnaire about gamification in the professional activities of coaches, supervisors, and business trainers was sent electronically to coaches, supervisors and business partners practising in Latvia. The questionnaire was sent to 130 supervisors, 100 coaches and approximately 80 business trainers, including the companies representing them. A link to the questionnaire was also created on specialised websites where the direct target audience can be reached, such as Linkedin, specialised websites on Facebook, including the page Latvijas kouci (Latvian Coaches) and others. The contact details of most of the supervisors whom the questionnaire was sent to can be found on the website of the Latvian Association of Supervisors. The research study was conducted between January and May 2020.

Participants. As a result, correctly completed questionnaires from 85 respondents were received and processed. 41 or $48 \%$ supervisors, 31 or $37 \%$ business trainers and 13 or $15 \%$ coaches took part in the survey. Most or $29 \%$ of the respondents have been operating in organisational consulting for up to five years, and a very similar amount, i.e., $26 \%$, of the respondents have experience of 6 to 10 years. $21 \%$ of the respondents have just started their professional career, $13 \%$ of the respondents have long-term experience of 11 to 15 years, and $11 \%$ have been operating in this area for more than 16 years. Most or $46 \%$ of the respondents in the research study represent the age group of 40 to 49 years, the next largest group with $27 \%$ of the respondents is 30 to 39 years, followed by the age group of 50 to 59 years, represented by $22 \%$ of the respondents. The groups represented the least are $60+$ years and below 29 years, represented by $1 \%$ and $4 \%$ of the respondents respectively. The vast majority of the respondents are females (84\%), and $16 \%$ are males.

Instrumentation. The aim of the survey was to find out the opinions of organisational consultants (coaches, supervisors and business trainers) about the use of gamification in organisational consulting. The questionnaire developed by the authors of the research study consists of the following parts: the first question determines the area of consulting, namely, whether the respondent is a coach, a supervisor or a business trainer. If the respondent has several roles, the questionnaire has "Mark the main one" as an option. The further completion of the questionnaire should be based on this main role. The questionnaire begins with two questions regarding associations: the first one is about a single word the respondents associate with the concept 'Game', and the second one is about what they associate 'Gamification' with. The questionnaire consists of 4 sets of items or scales with statements, with the responses to them provided in a Likert scale of 1 to 4 where " 1 " is 'disagree entirely', " 2 " is 'rather disagree', " 3 " is 'rather agree', and " 4 " is 'agree entirely'). The statements of the first scale are regarding the information available to the gamification consultants, it comprises seven statements (Information About Gamification). The second scale refers to the application and availability of gamification in terms of games and in the context of costs, and it comprises five statements (Application and Availability of Gamification). The third scale is about the belief of the consultants in the gamification methods, it comprises 10 statements (Believing Gamification Methods). The fourth scale is about the participants in gamification and their responsiveness and engagement in it, and it comprises 5 statements (Team/Group Responsiveness to Gamification). There are also two additional statements whose purpose is to additionally confirm the responses given by the respondents regarding their belief in gamification and readiness to use it. They are the following: 1. I believe gamification as an effective method in organisational consulting (Q1); 2. I am planning to apply gamification methods in organisational consulting within the nearest year $(\mathrm{Q} 2)$. The respondents had to rate the last two statements on a Likert scale of 1 to 7 , where " 1 " is 'disagree entirely' and "7" id 'agree entirely'.

Data processing methods: methods of descriptive statistics and methods of conclusive statistics were used for the processing of the data. The statistical analysis was carried out using the IBM SPSS 23.0 statistical data processing software. Research study restrictions: the research study restrictions relate to an insufficient study sample. Additional research studies need to be conducted to research the given problem with a larger study sample. 


\section{Results and Discussion}

The reliability of the internal content of the survey was verified using the Cronbach's Alpha coefficient. The total value is 0.896 , and this suggests that it is good, close to excellent. The Kolmogorov - Smirnov test (K-S test) has been performed, and the data show that only one scale, Believing Gamification Methods) corresponds to the normal distribution, because it is the only one with sig $\geq 0.05$.

Since one of the questions in the research study is whether there are statistically significant differences between various types of consulting (coaches, supervisors, business trainers), the non-parametric analysis method was used for a comparison of three and more groups using the Kruskal-Wallis test. As shown in Table 1, the four principal scales and the two additional questions have a sig $\geq 0.05$, and this means that there are no statistically significant differences between the types of consulting. Although, regarding Q2, the study sample has no statistically significant differences between the groups $(\mathrm{sig}=0.078)$, the significance is pretty low, and this means that, potentially, a larger number of respondents would result in significant differences.

Table 1

\section{Kruskall-Wallis test results for the determination of the differences between the groups of respondents}

\begin{tabular}{|l|l|c|c|c|c|c|c|}
\cline { 3 - 7 } \multicolumn{2}{l|}{} & $\begin{array}{c}\text { Information } \\
\text { About } \\
\text { Gamification }\end{array}$ & $\begin{array}{c}\text { Application and } \\
\text { Availability of } \\
\text { Gamification }\end{array}$ & $\begin{array}{c}\text { Believing } \\
\text { Gamification } \\
\text { Methods }\end{array}$ & $\begin{array}{c}\text { Team/Group } \\
\text { Responsiveness to } \\
\text { Gamification } \\
\text { Methods }\end{array}$ & Q1 & Q2 \\
\hline Coaches & \multirow{2}{*}{$\begin{array}{l}\text { Mean } \\
\text { rank }\end{array}$} & 47.73 & 43.42 & 46.08 & 37.46 & 46.54 & 44.31 \\
\cline { 1 - 8 } & 42.48 & 38.11 & 39.23 & 40.77 & 40.07 & 37.26 \\
\hline $\begin{array}{l}\text { Supervisors } \\
\text { trainers }\end{array}$ & 41.71 & 49.29 & 46.69 & 48.27 & 45.39 & 50.05 \\
\hline & $\begin{array}{l}\text { Asymp. } \\
\text { Sig. }\end{array}$ & $\mathbf{0 . 7 4 5}$ & $\mathbf{0 . 1 5 8}$ & $\mathbf{0 . 3 9 3}$ & $\mathbf{0 . 2 4 1}$ & $\mathbf{0 . 5 4 2}$ & $\mathbf{0 . 0 7 8}$ \\
\hline
\end{tabular}

The calculation of the correlation was done using the Spearman's correlation coefficient determination test (because the data do not correspond to the normal distribution). There is a weak correlation between the following scales: Information About Gamification and Team/Group Responsiveness to Gamification, where the correlation coefficient is 0.269 . There is also a correlation between: Team/Group Responsiveness to Gamification and Q1 and Q2 (or two additional questions), 0.360 and 0.343 , respectively. A statistically strong correlation, characterised by a coefficient of 0.6 to 0.8 , is between the following scales: Information about Gamification and Application and Availability of Gamification, which is logical; and means that the more information there is, the more opportunities are sought for and the more gamification is used among the consultants, and between: Believing Gamification Method and Q1 and consequently, the higher the Belief in Method scores, the higher the score on the two additional questions, and this confirms belief in and readiness to use gamification in organisational consulting within the nearest year (Table 2).

Table 2

Correlation between the principal scales of the questionnaire and the additional questions

\begin{tabular}{|c|c|c|c|c|c|}
\hline $\begin{array}{c}\text { Information } \\
\text { About } \\
\text { Gamification }\end{array}$ & $\begin{array}{c}\text { Application and } \\
\text { Availability of } \\
\text { Gamification }\end{array}$ & $\begin{array}{c}\text { Believing } \\
\text { Gamification } \\
\text { Methods }\end{array}$ & $\begin{array}{c}\text { Team / Group } \\
\text { Responsiveness to } \\
\text { Gamification }\end{array}$ & Q1 & Q2 \\
\hline $\mathbf{1 . 0 0}$ & $0.626^{* *}$ & $0.507^{* *}$ & $0.269^{*}$ & $0.443 * *$ & $0.493^{* *}$ \\
\hline & 1.00 & $0.690^{* *}$ & $0.431^{* *}$ & $0.580^{* *}$ & $0.780^{* *}$ \\
\hline & & 1.00 & $0.505^{* *}$ & $0.675^{* *}$ & $0.621^{* *}$ \\
\hline & & & 1.00 & $0.360^{* *}$ & $0.343^{* *}$ \\
\hline & & & & 1.00 & $0.587 * *$ \\
\hline & & & & & $\mathbf{1 . 0 0}$ \\
\hline
\end{tabular}

** Correlation is significant at the 0.01 level: $\mathrm{p}(\mathrm{sig})<0.01$

* Correlation is significant at the 0.05 level: $\mathrm{p}$ ( $\mathrm{sig})<0.05$

The first scale is about the information available to the consultants regarding gamification. More than half or $55 \%$ of the respondents disagree or rather disagree with the statement, that they know where to learn gamification methods in Latvia and $46 \%$ disagree or rather disagree that organisations in Latvia 
have information about the possibilities of using gamification. At the same time, $91 \%$ of the respondents indicate that they are willing to acquire the methods of gamification, and $80 \%$ would use gamification more often if they had acquired them (Table 1).

I would use gamification more often if I had acquired the methods of using it

I would like to acquire gamification methods

I know where to learn gamification methods in

$$
\text { Latvia }
$$

I would use the gamification more often if I had more information about it

I know where to look for information about gamification if I need it

I have enough information available about the possibilities of using gamification

Organisations in Latvia have information about the possibilities of using gamification

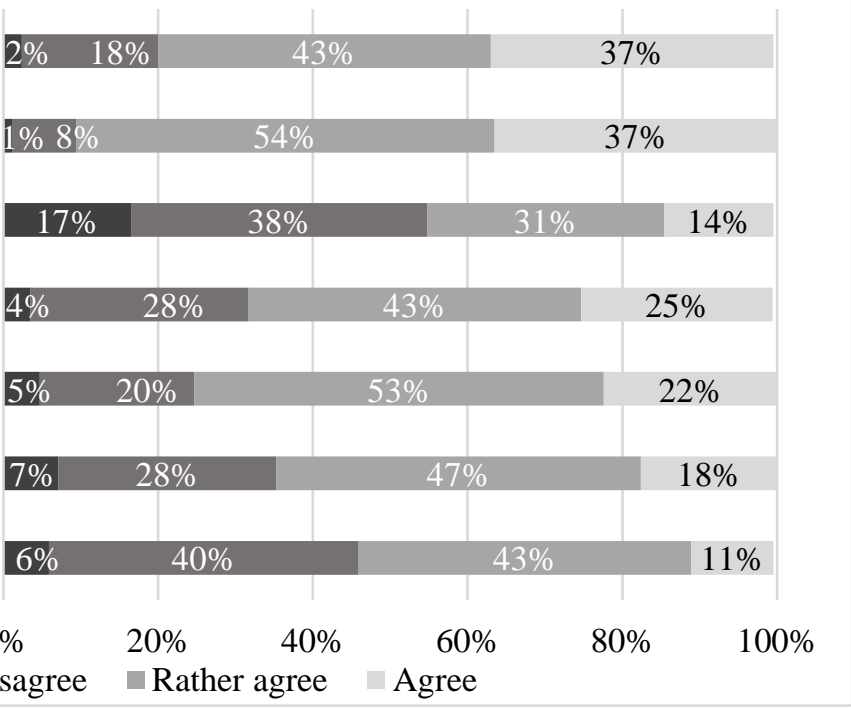

Figure 1. Summary of the responses provided by the respondents for the Information about Gamification scale $(\mathrm{n}=85)$.

The second scale is about the application and availability of gamification among the consultants. Most of the respondents $(74 \%)$ rather disagree or disagree with the statement that gamification is a frequently used method in organisational consulting in Latvia, with only $1 \%$ indicating that they agree with this statement. $81 \%$ indicate that they would use gamification more often if a wider range of games and their elements was available. At the same time, $66 \%$ of the respondents have gamification tools available for organisational consulting. To the fourth statement, which is about whether the consultants apply gamification in organisational consulting, $60 \%$ of the respondents have provided responses that they rather agree or agree with the statement. Respectively, the response to the first research question (whether gamification is used in organisational consulting in Latvia) is yes (Figure 2).

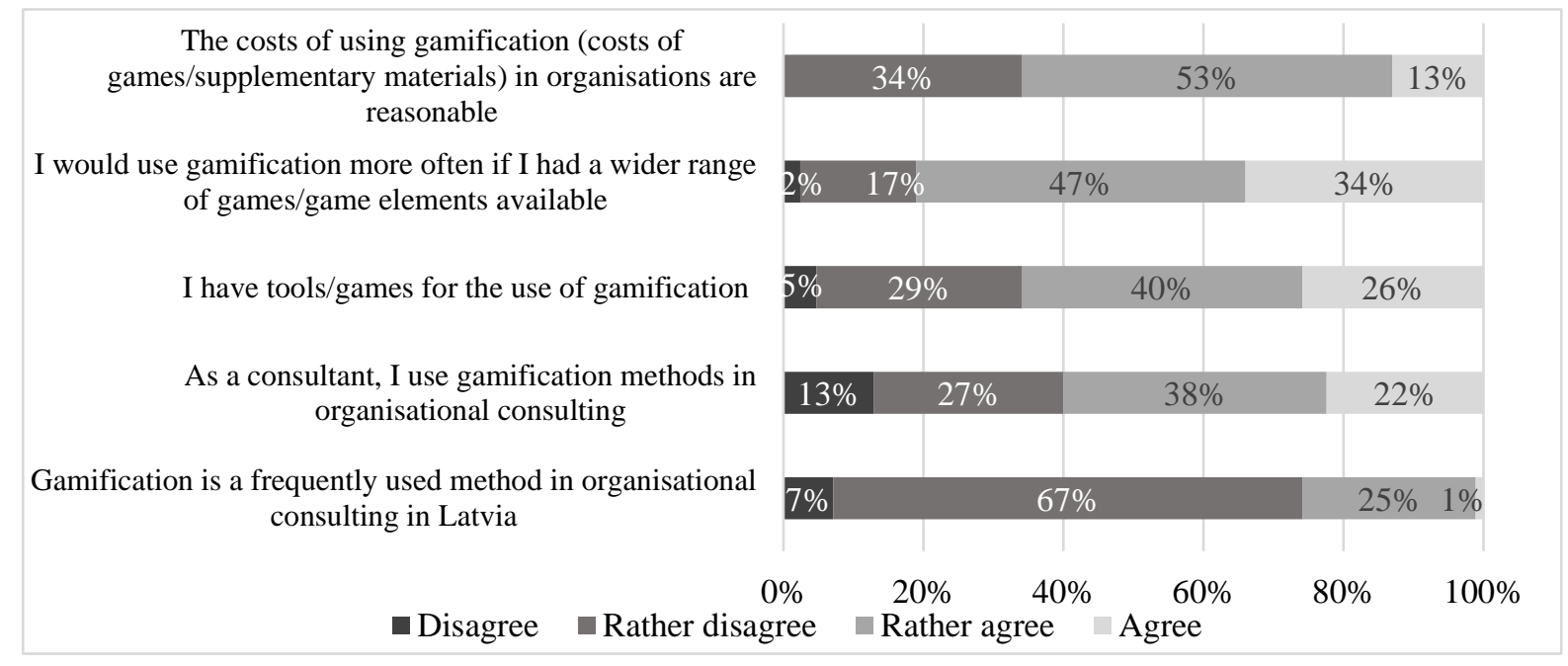

Figure 2. Summary of the responses provided by the respondents for the Application and Availability of Gamification scale $(n=85)$.

When viewing the scale's responses by the groups of respondents, the most substantial difference among the consultants is for the availability of games/tools, where $46 \%$ of the supervisors respond with 'disagree' or 'rather disagree'. For the coaches and business trainers, this score is $15 \%$ and $34 \%$ respectively, and this is comparatively lower. The third scale is about believing the gamification methods as efficient methods in organisational consulting. The statements of this scale have practically no 'disagree' responses. An exception 
is the reversibly analysed statement that gamification is just a tool for entertaining the team/group with no significant impact on the result, as $77 \%$ of the respondents either disagree or rather disagree with this statement. The highest 'rather agree' and 'agree' score, which is $100 \%$, is for the statement that the use of gamification facilitates engagement of the participants (Figure 3). The respondents believe the positive effect of using gamification, which is also $100 \%$, the statement "I like Gamification" also has a high score (98\%), and the score for the "The use of gamification facilitates openness of the participants" is $97 \%$

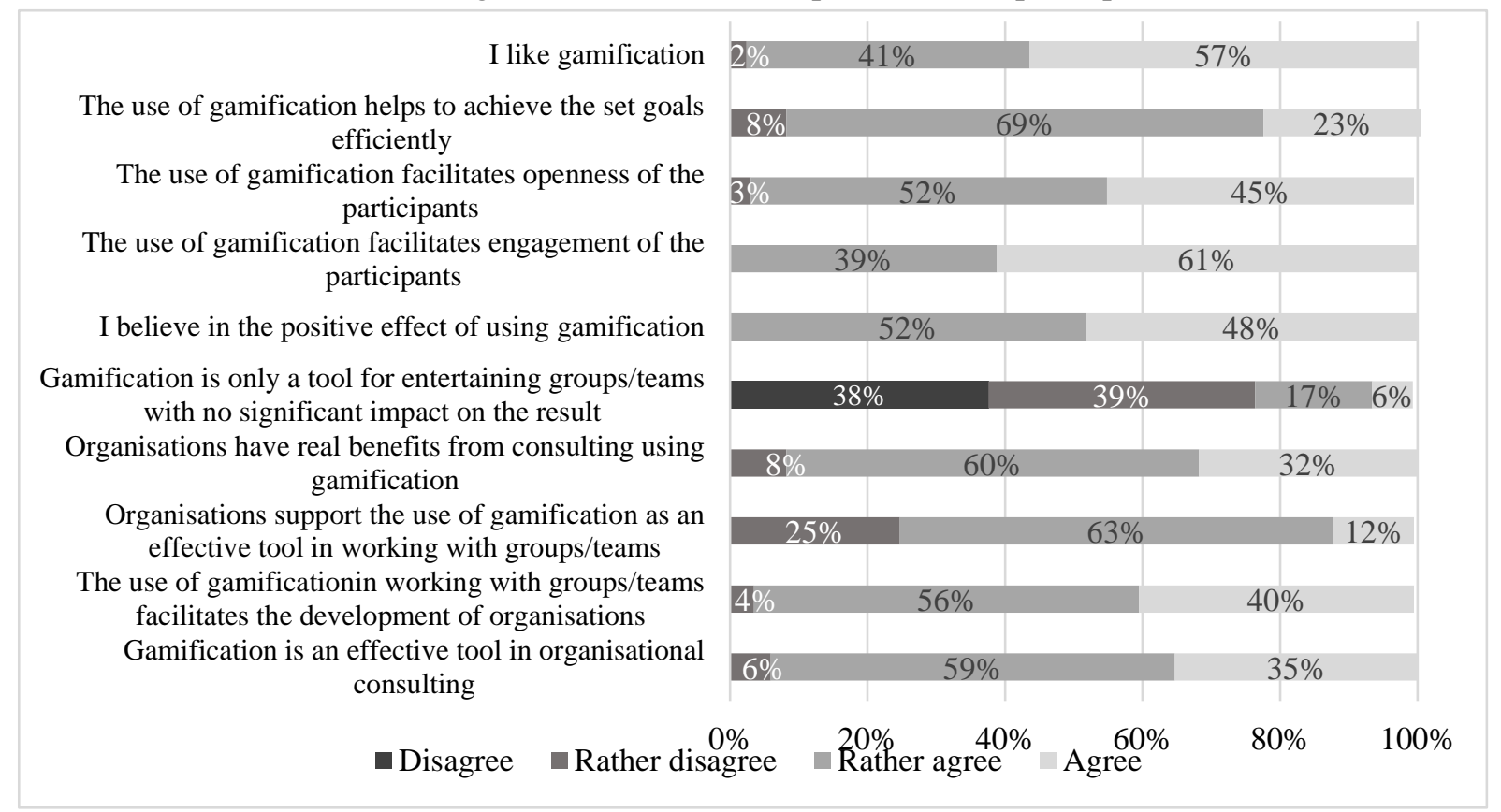

Figure 3. Summary of the responses provided by the respondents for the Believing Gamification Methods scale $(\mathrm{n}=85)$.

The fourth scale is about the participants in gamification and their responsiveness to gamification. It comprises 5 statements, with two of them to be analysed reversibly. No 'disagree' responses have been received to the last three statements of this scale, and there are also few 'rather disagree' responses. $9 \%$ of the respondents have provided 'rather disagree' responses to the statement about the positive perception of gamification, and $13 \%$ of the respondents have responded with this to the engagement of the teams/groups in the gamification process. The results suggest group and team interest, openness and engagement in the process of gamification (Figure 4).

It is hard to engage team/group participants in gamified activities

Team/group participants do not trust the gamification methods

Team/group participants are interested in using gamification

Team/group participants feel positive about the use of gamification

Team/group participants are open to the gamification process

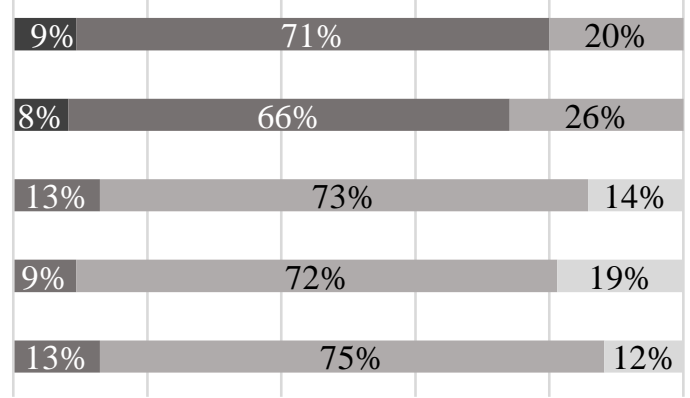

$\begin{array}{cccccc}0 \% & 20 \% & 40 \% & 60 \% & 80 \% & 100 \%\end{array}$

Figure 4. Summary of the responses provided by the respondents for the Team/Group Responsiveness to Gamification scale ( $\mathrm{n}=85)$.

As mentioned previously, the questionnaire includes two questions regarding associations: the first one is about a single word the respondents associate with the concept 'Game'. The second one is regarding what they associate with 'Gamification'. The first associations were summarised for the word 'Game'. 
The results suggest that the most frequent (15 times) association appearing in the responses provided by the respondents can be characterised by the word 'interesting'. The further words are: fun, joy and cheerful (repeated in the responses 13 and 12 times respectively). Frequently mentioned associations are excitement, fascinating, creativity, competition, childhood, rules, easy.

For demonstration purposes, the associations with the word 'Gamification' are shown using a cloud of words (Figure 5). The words most frequently mentioned by the respondents for their associations with the concept Gamification' are: interesting, fun and excitement. In addition to these specific associations with gamification, different from the associations with a game, there are words like team, learning, engagement. It should be noted that, in the context of gamification, in contrast to a game, there are negative associations as well - disbelief, manipulation, not till the end, resistance, artificiality, nonLatvian, cunning and others. There were about 80 unique associations for the word "Gamification", only the most frequently mentioned are included in the cloud of words (Figure 5). For the word "Game" there were mentioned more than 100 unique associations.

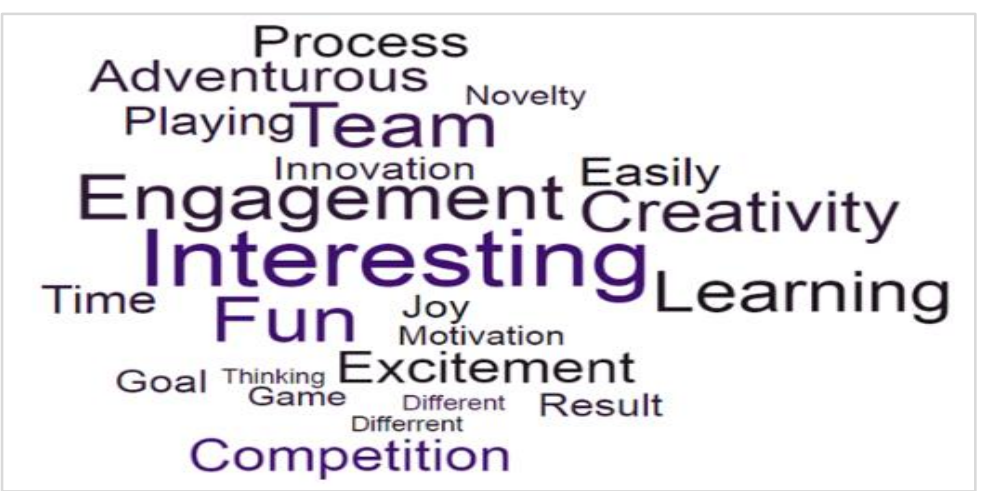

Figure 5. The cloud of words for association with the concept 'Gamification' ( $\mathrm{n}=85)$.

These results are similar to the results of other conducted research studies where gamification has been recognised as one of the increasingly frequently used methods in corporate learning and business training where partially or fully gamified systems are used to meet most of the corporate training needs (Pandey, 2019), and it is considered to be an innovative solution to facilitate motivation (Dulskaia et al., 2017). By using gamification in training, organisations can improve the engagement of the employees, increase productivity and improve operational performance (Gamification..., 2012; Zichermann, Linder, 2013; McCormick, 2013; Bruke, 2014; Dulskaia et al., 2017). Similar results have been obtained in Latvia as well, where two groups of participants responded to the same questions in a survey about gamification. The survey shows that $89 \%$ of employees believe that they would be more productive if they had more tools with game elements, such as collaboration or inner communication tools. The results of the research study show that learning with gamification provides significantly higher motivation (by even $83 \%$ ), compared to the score of $28 \%$ without gamification, boredom drops from $49 \%$ to $10 \%$, and only $3 \%$ of the respondents feel non-productive in learning with the use of gamification (Dudko, 2020). Therefore, it is essential to proceed with research studies to find out the experience of organisations in gamification. For example, whether gamification is used in organisations, to what extent and what games, for what purposes and what the short-term and long-term benefits the organisations have from gamification.

\section{Conclusions}

The results of the research study show that gamification is applied in organisational consulting, but $74 \%$ of the respondents still mention that gamification is not a frequently used method in Latvia. The level of belief in gamification as an effective method in organisational consulting is high, and $73 \%$ of the respondents have specified that they are planning to use gamification in organisational consulting within the nearest year. The theory and the results of the research study lead to a conclusion that organisations see substantial benefits in the use of gamification, because $75 \%$ of the respondents have responded positively to organisational support to the use of gamification as an effective tool in working with teams or groups.

The concept of gamification has not been sufficiently explained and there is still no common understanding regarding it in Latvia. There is very limited information regarding the theoretical approaches to gamification, 
the views of various globally renowned experts, or successful game designs. In the meantime, new companies are emerging and offering gamification platforms for organisations and employees, and this suggests that gamification is developing in Latvia. Organisational consultants have insufficient information about the opportunities for acquiring gamification and methods of gamification. This is suggested by some of the results of the research study, such as the low levels of knowledge about the opportunities for the acquisition of gamification and its methods (more than half or $55 \%$ of the 85 respondents do not know where they can be acquired). At the same time, $91 \%$ of the respondents indicate that they are willing to acquire the methods of gamification, and $80 \%$ would use gamification more often if they had acquired them. This suggests that game developers have vast opportunities in this field. Although only approximately $34 \%$ of the respondents indicate that do not have the necessary tools/games for using gamification, $81 \%$ of the respondents state that they would use gamification more often if they had a wider range of games available.

There are no statistically significant differences in the opinions of the coaches, supervisors and business trainers regarding the use of gamification in organisational consultation-Nevertheless, business trainers and coaches plan to use gamification within the nearest year more frequently than supervisors. Although statistically insignificant, there are differences in the availability of games: $46 \%$ of the respondents have responded 'rather disagree' or 'disagree' to the statement "I have tools/games for the use of gamification", whereas this score is not that negative for coaches and business trainers (15\% and $34 \%$ respectively).

The authors of the study believe that it is important to proceed with the research in organisations to find out the experience of the organisations in gamification and to develop gamification training offerings and programmes for organisations.

\section{Bibliography}

1. Bishop J. (2014). Gamification for Human Factors Integration: Social, Education, and Psychological Issues. Hershey, Pennsylvania, USA: IGI Global. doi: 10.4018/978-1-4666-5071-8

2. Bruke B. (2014). Gamify: how gamification motivates people to do extraordinary things. New York: Routledge.

3. Ceḷā pie laimīgiem darbiniekiem. Iekšējās komunikācijas platforma darbinieku iesaistei un noverrtēšanai [On the way to happy employees. Internal communication platform for employee involvement and evaluation]. (2020). Benefits Latvija. Retrieved from http://benefits.lv/ (in Latvian)

4. Chou Y. K. (2019). Actionable gamification: Beyond Points, Badges, and Leaderboards. Milpitas: Octalysis Media.

5. Deterding S., Sicart M., Nacke L., Dixon D. (2011). Gamification - using Game-Design Elements in Non-Gaming Contexts. CHI EA 11 Proceedings of the 2011 Annual Extended Abstracts on Human Factors in Computing Systems. New York NY: Association for Computing Machinery, 2425-2428. doi: 10.1145/1979742.1979575

6. Dudko K. (2020). Spēlıšana personālvadības procesos [A customizable HR solution with gaming elements]. Retrieved from https://squalio.com/lv/blogs/spelosana-personalvadibas-procesos/ (in Latvian)

7. Dulskaia I., Bellini F., Zabal R., Pañella O.G., D'Ascenzo F. (2017). Gamification as an instrument for organizational behaviour change during the meeting: case study "ROBATIEMPOS" In The Proceedings of the International Conference Business Excellence 11(1), 359-367-275. doi: 10.1515/picbe-2017-0039

8. Efectio programmu piedāvājums darbinieku iesaistei. [Efectio program offer for employee involvement]. (2020). Retrieved from https://efectio.lv/platforma/ (in Latvian)

9. Ërgle D. (2020). The Impact of Gamification on Employee Engagement in A Complex System of Human Resource Management Processes. Retrieved from https://dspace.lu.lv/dspace/handle/7/50300

10. Gamification Market - Growth, Trends, and Forecasts (2020 - 2025). (2020). Mordor Intelligence. Retrieved from https://www.mordorintelligence.com/industry-reports/gamification-market

11. Gamification: Engagement Strategies for Business and IT. Gartner Research. (2012). Gartner, Inc. Retrieved from https://www.gartner.com/en/documents/2246217/gamification-engagementstrategies-for-business-and-it 
12. Hayward B. (2017). The Gamification of Customer Behaviours. Credit Control, 38(1/2), 36-40.

13. How to Succeed with Digital Gamification for Youth Engagement. (2018). Social Innovation Centre Retrieved from http://socialinnovation.lv/wp-content/uploads/2013/12/GAMIENG_fullversion_web.pdf

14. Joy M.M. (2020). Playbour: Gamification for Employee Engagement. Kerala: Independently published.

15. Kapp K.M. (2012). The Gamification of Learning and Instruction: Game-based Methods and Strategies for Training and Education. San Francisco: John Wiley \& Sons.

16. Lukashenia Z., Levanova E., Tamarskaia N. (2020). Use of Gamification as a Means of Consulting Support for Continuous Professional Development of Teachers. In V. Dislere (Ed.), The Proceedings of the International Scientific Conference Rural Environment. Education. Personality (REEP), 13. Jelgava: Latvia University of Life Sciences and Technologies, 428-434. doi: 10.22616/REEP.2020.050

17. Mathieson S.A. (2017). Play the motivation game to inspire workers. Computer weekly, (17)12, 19-23.

18. McCormick T. (2013). Anthropology of an idea gamification. Foreign Policy, (201), 26-27.

19. Padgett L. (2013). Your Best Game Face. Information Today, 30(1), 25-25.

20. Pandey A. (2019). Gamification Trends in 2019 - Packed with Tips and Ideas You Can Use. Retrieved from https://elearningindustry.com/gamification-trends-2019-tips-ideas-packed

21. Par mums [About us]. (2018). Tavas Metodes. Retrieved from http://www.tavasmetodes.lv/parmums/ (in Latvian)

22. Rūsa L. (2016). Spēḷota darba vietā [Gamification in the workplace] Retrieved from http://www.eiropersonals.lv/aktualitates/2016/11/28/spelota-darba-vieta-komentars-zurnalamibizness (in Latvian)

23. Saran C. (2015). A Business Case for Gameplay at Work. Computer weekly, August, 19-22.

24. Schnell J. (2010). Design Outside the Box Presentation. DICE 2010. [Video file]. Retrieved from https://www.youtube.com/watch?v=nG_PbHVW5cQ

25. Zichermann G., Linder J. (2013). The Gamification Revolution: How Leaders Leverage Game Mechanics to Crush the Competition. New York: McGraw-Hill Education.

26. Zinger D. (2014). Game on: A Primer on Gamification for Managers. T+D. May, 68(5), 30-35. 